\title{
Adoption of IFRS as a Strategy for Captial Flight In The Third World Countries
}

\author{
Ude Alexander Onyebuchi \\ Department of Accountancy \\ Ebonyi State University Abakaliki \\ Chiontus@yahoo.com
}

\begin{abstract}
International financial reporting standard (IFRS) is a set of accounting standard that stipulate on how transaction and events should be reported in the financial statement to bring a quality and uniformed set of financial reporting that will help curtailing capital flight in third world countries. Capital flight represents a higher burden in Africa, as a percentage of GDP, than in other regions. The sum that leaves developing countries as unreported outflows amounts to ten times the annual global aid flows, and twice the debt service developing countries pay each year. The capital outflows from Africa and the absorption into western economies deserve attention and require concerted effort. To end the secrecy that enables it, there must be an automatic and multilateral exchange of information between various government authorities, as well as imposition of sanctions on noncompliance, and also the need to require multinational companies to report the profit they make and taxes they pay in each country where they operate which could be mandatory if made part of international financial reporting standard (IFRS). Putting an end to capital flight is an urgent matter of global justice of bringing the billions back to where they were produced and where they should contribute to the welfare of the people.
\end{abstract}

\section{Introduction}

According to the Deliotte (2012), the term international financial reporting system has both a narrow and a broad meaning. Narrowly it refers to the new numbered series of pronouncements that the IASB is issuing as distinct from the international accounting standard (IASs) series. More broadly, it refers to the entire body of IASB pronouncement including standards and interpretation approved by the predecessor international accounting standard committee. In other words, it is a set of international accounting standard stating how particular types of transactions and other events should be reported in financial statement. The main goal is to make international comparisons as easy as possible, though this is difficult to a large extent, as each country has its own set of rule. Also as Land and Lang (2002) document that accounting qualities has improved worldwide since the beginning of 1990s and suggest that it could be as a result of globalization and anticipation of international accounting harmonization. However, still each year US\$1. 26 trillion-US\$1. 44 trillion ( $\mathrm{N} 230.4$ trillion) disappear without trace from developing countries as unreported financial outflow in form of capital flight (Manuel 2008). Capital flight usually refers to as the deliberate stripping away of the resources of a country and their expatriate overseas, and is a massive problem for developing countries and their effort to challenge poverty. Both the Monterrey and Doha financing for developing conference, in (2002 and 2008) respectively and at the Millennium Development Goals (MDG) review conference (2010), capital flight was singled out as a significant barrier to be overcome by developing countries seeking to raise more revenue domestically. Capital flight in economics occurs when assets or money rapidly flow out of a country, due to an event of economic consequences. Such 
event could be an increase in taxes on its capital holders or the government of the country defaulting on its debt that disturb investors and causes them to lower their valuation of the assets in that country or otherwise to loses confidence in its economics strength (Young and Guenther, 2002).

This leads to a disappearance of wealth and is usually accompanied by a sharp drop in the exchange rate regime or forced devaluation in a fixed exchange rate regime (Baker 2007). The falls particularly damaging when the capital belongs to the people of the effected country, because not only are the citizens now burdened by the loss of faith in the economy and devaluation of their currency, but probably also assets have lost much of their nominal value. This leads to dramatic decrease in the purchasing power of the country's asset and makes it increasing expensive to improve goods (Land and Lang 2002).

Account theory argues that the purpose of financial reporting is essentially to reduce information asymmetry between corporate managers and parties contracting with their firm (Ball, 2001), and Financial reporting reduces information asymmetry by disclosing relevant and timely information, because there is considerable variation in accounting quality and economic efficiency across countries international accounting systems providing an interesting setting to examine the economic consequences of financial reporting (Eurodad 2008). Improvement in the information environment following changes to IAS and thus assist in controlling the economic activity that can result in capital flight

\subsection{Review of Related Literature}

The financial health of global financial market is important to dominant nation state as they pursue "intentional politics and policies to enhance their wealth (Arnold and Silk 2001), and it is also important to emerging economies and developing countries as they seek to participate in the wealth promised by the adoption of globalized business practices including the adoption of a set of globalized accounting standards. The convergence of many national generally accepted accounting principles (GAAP) with international financial reporting standard (IFRS) (Fortes et al 2005) promises transparent, comparable and consistent financial information to guide investors in making optional investment decision (Jacob and Madu 2004). Developing countries have recognized their need to participate in the opportunities offered by globalization (United Nations assembly 2004). And in consequence have led the way in adopting IFRS (IAS plus, 2006). However, numerous studies questioned the relevance of IFRS to developing countries (Mir. and Ramahan, 2005), and drew attention to the need for contextualized studies of accounting (Reiter, 2000) while emerging economies typically enjoy greater wealthy than developing countries and therefore do not face the financial constraints, they nevertheless face many similar challenges in adopting IFRS in terms of changing culture and developing systems of regulation and accountability and adopting IFRS, Kar and Cartwright -Smith (2010), it nevertheless has challenges ahead of developing countries as they make necessary reforms of it regulatory, legal and economic structure and adapts its culture to westernized forms of expression.

\subsection{Globalized Accounting Standards}


While not a recent phenomenon, the process of globalization has accelerated in the last twenty years, promoting greater interdependence between economies, operating as a universalizating process, and promising greater wealth and a decrease in poverty for all economies through the "logic of capitalism" (Clifford, 2000). As envisaged by the "Washington consensus" and propounded by the world bank (suttle 2003) the international monetary fund (IMF) and the organization for economics cooperation and Development (OECD), globalization currently proposes that borders should be "porous" (Harris, 2002) and that by implementing policies such as free trade, privatization, deregulation, fiscal discipline and tax reform, the result will be economic growth for developing and developed countries alike (stigiltz, 2001) described as a "worldwide pressure for changes" (Granell, 2000) globalization has polarized opinion and it is much more than an economic phenomenon for the developing world, having wide ranging effect, with both winners and losers. While its proposed benefit is substantial, global capitalism nevertheless has a downside. By embracing globalization, whole societies are disrupted (Engaridio and Belton, 2000) and the cultural uniqueness of nations is threatened by westerndominated ideologies and technologies. At the same time as millions of people benefit from foreign aid which establishes irrigation and education, there are profound changes in legal, regulatory and culture systems that have been in place for generations. This applies to emerging economics as well as developing countries as they face significant challenges in their cultural, legal and regulatory structures (Lazzeri 2001). Accounting has a role to play in the process of globalization, through the operation - multinational co-operations, the regulatory system of developed countries (Arnold and Sikka, 2001) and the prevalence of international accounting firms (Perea et al, 2003).

Consequently, IFRS is both in manifestation of globalization and technology by means of which globalization is mobilized. In 1973, the international accounting standard committee (IASC) was formed to work towards greater comparability between financial reports across countries (Alfredon et al, 2005). Since then and reconstituted as the international accounting standard board (IASB), it has grown in influence to the point where it now had almost 100 countries either converging or adopting IFRS (IASB 2006), although significantly none of the 14 country members of the IASB is from a developing nation (Jacob and Madu, 2004).

Substantial benefits have been proposed by the adoption of IFRS, including a decreased cost of capital, greater mobility of capital, greater efficiency in the allocation of resources, improved and more comparable financial reporting and a decrease in the opportunity of earning management (UNCTAD,2005). These together with the accountability demands of the world bank and the IMF (Nue and Gomez 2006) make a compelling case for the adoption of IFRS by developing countries and emerging economies as they seek to participate in the wealth and financial opportunities promised by globalization.

\section{Capital Flight in Developing World}

There is no widely accepted definition of capital flight. The classic use of the term is to described widespread currency speculation, especially when it leads to cross boarder movements of private funds that are large enough to affect national financial market. 
Capital flight represents a higher burden in developing country, as percentage of GDP than in developing countries (Lazzeri 2011). Capital flight in economic occurs when assets or money rapidly flow out of a country due to an event of economic consequences (Khanna, 2001), such event could be an increase in taxes on capital holders or the government of the country defaulting on its debt that disturbs investors and causes them to lower their valuation of the asset in that country or otherwise to loss confidence in its economic strength. The capital outflows from these developing countries require concerted effort (Floyed 2006). Capital flight is a massive problem for developing countries, which occurs through tax havens, internal trading, transfer mispricing, falsified invoicing etc. the need to stop capital flight especially the illicit capital flight must be taken by decision maker's in developing countries if they are to succeed (MDG), 2010).

Further more capital flight has enamors effect on the development of the third world countries such as conceals of investment, reduce tax collection, worsens income gaps, hurts competition, undermines trade and drains hard currency reserves (Granell, 2000). The flow of illicit money from developing countries is based on shifting the wealth out of the countries where $80 \%$ of the world's population lives into countries where $20 \%$ live. Baker (2002) calls illicit capital "the most damaging economics condition hurting the poor in developing and transnational economies". He comes to the conclusion that for the first time in the 200 years run of the free market system we have built and expanded an entire integrated global financial structure with the purpose to shift money from the poor to the rich. Christian Aid has estimated that due to just two forms of capital flight (mispricing and false invoicing by multinational companies) developing countries are losing $\$ 160$ billion per year in tax revenue (Engardio and Belton, 2000). This is more than one and half times the combined aid budgets of the entire rich world, which is around $\$ 100$ billion. Taking into account additional sums from aggressive tax avoidance and other forms of trade abuse, the total loss of tax revenue is several times that amount (MDG2010). Kar and Cartwright-Smith (1010) the estimation of revenue lost through illicit capital flight have been made on tax developing countries pay today (Floyd 2006). At the individual level, illicit capital flight and tax evasion also create an unequal playing field and worsen income gaps. It is rich individuals that have the means to open an account in a tax haven and place money there without reporting it to their tax authorities (BALL,2001). When this is done, tax revenue that could have contributed to social services like health care and education is lost. The possibility to conduct illicit capital flight also makes criminal actives like human trafficking and illegal trade with weapons and drugs profitable and decrease the risk of getting apprehended (Kapoor,2007).

\section{Methodlogy}

The central question of this work is whether the adoption of IFRS helps in capital flight means that, it is an area dependent upon peoples subjective opinion on various issues related to IFRS.

...Questionnaires were administered to twenty (20) relevant senior staff of selected federal ministries in the country (ministries of finance, commerce and industry; petroleum).

...Review of relevant literature, including newspapers, magazines, professional accounting journal was also done.

\section{Data Analysis}


Data collected will be analyzed using table, SPSS including narratives as may be considered suitable. The purpose will be to establish trends, make inferences, and drew conclusion to the problem and questions already enumerated.

\section{Statistical Test of Hypothesis (Using Spss-Version 16)}

\begin{tabular}{|c|l|l|l|l|}
\hline Y & $\mathrm{X} 1$ & $\mathrm{X} 2$ & $\mathrm{X} 3$ & $4 \mathrm{X}$ \\
\hline 20 & 2 & 17 & 1 & 0 \\
\hline 20 & 1 & 12 & 7 & 0 \\
\hline 20 & 1 & 1 & 4 & 14 \\
\hline 20 & 0 & 2 & 2 & 16 \\
\hline 20 & 1 & 0 & 5 & 14 \\
\hline 11 & 4 & 1 & 6 & 0 \\
\hline 9 & 1 & 1 & 7 & 3 \\
\hline 12 & 6 & 2 & 1 & 0 \\
\hline 13 & 2 & 1 & 4 & 6 \\
\hline$\sum \mathrm{xn}=145$ & 18 & 37 & 37 & 53 \\
\hline
\end{tabular}

Source:" field survey from questionnaire

\section{Hypothesis:}

Ho: $\mu$ : The adoption of IFRS will have no significant impact in the reduction of capital Flight in Third World Countries.

Hi: $\mu$ The adoption of IFRS will have significant impact in the reduction of capital flight in Third Word Countries

\section{Computer Print Coefficients}

Unstandardized Coefficients

\begin{tabular}{|l|l|l|l|}
\hline MODEL & B & Std. Error & T \\
\hline Constant & -23.315 & 3.557 & -4.372 \\
\hline X1 & 0.337 & 0.114 & 2.890 \\
\hline X2 & $9.090 \mathrm{E}-02$ & 0.072 & 1.280 \\
\hline X3 & 1.253 & 0.090 & 12.890 \\
\hline X4 & 1.240 & 0.081 & 13.670 \\
\hline
\end{tabular}

Source: SPSS Version 16

$\mathrm{Y}=\mathrm{B} 0+\mathrm{B} 1 \times 1+\mathrm{B} 2 \times 2+\mathrm{B} 3 \times 3+\mathrm{U}$

From SPSS analysis:

$\mathrm{Bo}=-23.315, \mathrm{~B} 1=0.337, \mathrm{~B} 2=9.090 \mathrm{E}=0.0909, \mathrm{~B} 3=1.253, \mathrm{~B} 4=1.240$ 
$\mathrm{Y}=23.315+0.337 \times 1+0.090 \times 2+1.25 \times 3+1.240 \times 4$

Degree of freedom: $(\mathrm{n}-\mathrm{k})(9-4)=4$

T-calculated $=30.73$

T-(tabulated) $4,0.05= \pm 2.132$

\section{Decision}

Hence, $\mathrm{T}$ - tabulated is less than T-calculated; we reject the Null Hypothesis (Ho) and accept Alternative Hypothesis (Hi) claiming that the adoption of IFRS will have significant impact in the reduction of capital flight in Third World Countries

\section{Conclusion}

Adoption of IFRS should reduce artificial differences in profitability caused by opaque domestic accounting standards of some countries. If globalization and IFRS have these effect, accounting practices should become more uniform across countries over time and thus help in reducing capital flight in third world, it is time to say adoption of IFRS is relatively simple but its implementation is not, as the developing countries faces challenges if they are to make it reliable, regulated reality and not just an image. To end the security that enables it, therefore example calls for automatic and multilateral exchange of information between tax authorities, as well as imposition on tax havens that do not cooperate (Baker 2008). Another measure would be to require multinational companies to report the profit they make and taxes they pay in such country where they operate. This could become mandatory if it was made part of the international financial reporting standards (Brown 2009).

There is also a need for specific measures at the country level, such measures include the building of frameworks better suited to address the problem, awareness raising about the link between tax evasion, tax revenue and social services, as well as capacity building of tax authorities (Asbaugh, 2001). International cooperation to stem capital flight ultimately has to be dealt with in a representative global body like the U.N. For this reason, developmental organizations in the developed and developing countries, call for the UN committee on tax mattes to be upgraded with a political mandate and strengthened (UNDTAD,2005). Putting an end to illicit capital flight is an urgent matter of global justice of bringing the billion back to where they were produced and where they should contribute to the welfare of the people (Baker 2008). At the same time, it is win-win opportunity for developed and developing countries as they both suffer from illicit capital and the loss of growth and tax revenue that comes with it. Both would gain from transparency that would counteract not just tax evasion but also illegal trade in drugs, weapons and humans to make it happen it is time for civil society, journalists and decision makers in developing countries to join cause (Daske, 2007). 


\section{Reference}

Annisefte, M (2004) "The true nature of the world bank "critical perspectives in accounting.

Arnold P.J and Sikka, P (2001) "Globalization and state profession relationship; the case the bank of credit and commerce international Accounting organization society, 26,pp 475499.

Ball, R (2005) Making accounting more international: why, how, far will it go, journal of Applied Accounting *2006) "Our locations" Http//www.Deloitte.com/dtt/articles/0, 1002 accessed 15 August 2012.

Ernest and Young (2006) "About EY in the middle east".

Heep://www.ey.com/global/download.nsf/international/FIDs,

Accessed 3 August 2012

Floyd, D. (2001) “Globalization or Europeanization of business activity' Exploring the critical issues" European business review, vol13.

Gordon, B. (2009) Speech to DFID conference on eliminating world poverty Global investment house 2005 www.number10.gov.uk/page18554

Global investment house 2005.2 available at http/.www.menereport.com/en//business,economyandtrade/192803.accessed 12 may 2012

Harris, P. R. (2002) "European challenge: developing global organization" European business review vol14, no 6, pp 416-426.

Jacob R. A. and Madu C, N. (2004) “Are we approaching a universal accounting language

Kawach N, (2003) "AE economy to swell to Dh 284.56" Avaliable online at http://www.datadudai.com/uaegdp-2003.htm.accessed 12may, 2012.

Kar, D. and Cartwright-Smith, D. (2008) illicit financial flows from developing countries 20022006, Global Financial Integrity.

Land, J. and Lang, M. (2002) Empirical evidence on the evolution of international earnings, Accounting Review.

Manuel .T. (2008) address to the OECD forum on tax Administration.www.treasury.gov.za/co 